\title{
Financial Inclusion: Policies, Status, and Challenges in Palestine
}

\author{
Xiu Hua Wang ${ }^{1} \&$ Fadi Hassan Shihadeh ${ }^{2,3}$ \\ ${ }^{1}$ School of Finance and Statistics, Hunan University, Hunan, China \\ ${ }^{2}$ School of Economic and Trade, Hunan University, Hunan, China \\ ${ }^{3}$ Lecturer at Palestine Technical University, Kadoorie, West Bank, Palestine \\ Correspondence: Fadi Hassan Shihadeh, School of Economics and Trade, North Campus, Hunan University, \\ Yuelushan, Changsha, Hunan, 410079, People's Republic of China. Tel: 86-130-7734-6474. E-mail: \\ fadih20@gmail.com
}

Received: May 8, 2015

Accepted: May 22, 2015

Online Published: July 25, 2015

doi:10.5539/ijef.v7n8p196

URL: http://dx.doi.org/10.5539/ijef.v7n8p196

\begin{abstract}
Palestine suffers from unemployment and slow economic growth as a result of instability in political situation. To achieve the stability in the economic growth, the government is working through the policies and procedures to deliver the financial services to the poor and disadvantaged people in affordable cost which is called the financial inclusion. This paper was highlighted on the reality of the financial inclusion in Palestine through discussing the policies and instructions which are adopted by the financial authorities and financial services companies. The study used secondary data which was collected from differed sources to analyze and discuss the financial inclusion indicators and compare it with some countries in the area. In this paper a "stock market "was added as a new factor to the financial inclusion indicators (Access, usage, and quality) which was determined by Group 20. As the literature studies concluded that the relationship between the stock market and economic growth very strong. The study found that financial inclusion indicators was improved since Palestine has joined to the Alliance for Financial Inclusion in addition to the improvement in the infrastructure. But using the financial services are still limited specially the credit, and need more efforts to improve it. Also some countries in the area has good financial inclusion indicators as a result of political stability.
\end{abstract}

Keywords: financial inclusion, economic development, financial institutions, Palestine, GDP, indicator, government policies, PMA, PCMA

\section{Introduction}

Financial institutions, particularly banks, are regarded as the main drive of the economy of society, where they represent the mediator between units of surplus and deficits. These institutions provide the appropriate funding and financial liquidity, which helps create firms, jobs, and improve the level of economic development.

Countries aim to achieve comprehensive development through economic development and well-being of a society. They strive to provide the requirements of development by creating an environment encouraging the individuals and organizations to contribute actively in promoting economic development. Economic growth can be realized by financial institutions "to attract deposits, develop it, granting the credit and investment for individuals and firms in production and consumption". This role requires the government to work on finding the best ways to get the individuals and institutions in obtaining the appropriate funding in affordable costs.

In order to ensure the contribution of individuals and institutions in the economic process and the overall development in Palestine, the specialized financial institutions are seeking to ensure access to appropriate funding with affordable costs. The bulk of the population suffers from unemployment (Palestinian Central Bureau of Statistics, 2014) and lack financial resources. In addition, the exposure of the Palestinian areas for many wars and the lack of freedom of movement among the major cities and rural areas are contributing factors as well, hindering the freedom and ease of access for the people to the sources of funding when needed. The unemployment rate in Palestine was up 27\% (West Bank without East Jerusalem and Gaza Strip) in 2014.

To achieve economic growth, we need to include individuals and firms in the financial system at a reasonable cost, this is called financial inclusion. Financial inclusion is possible if open access is granted to rural areas and the poor. This represents a joint effort between all the relevant parties. Since the Palestine Monetary Authority 
(PMA) joined the Alliance for Financial Inclusion (AFI) in July 2010, talks began extensively about making the concept of financial inclusion in Palestine a reality. Several programs and instructions carried out by the PMA have urged banks to adopt, participate, and cooperate with other financial supervisory institutions in the process to ensure the improvement of financial inclusion.

\section{Literature Review}

Financial inclusion prompted many academic researches and technical studies throughout the world to measure the financial inclusion indicators and their impact on economic development while also comparing it between different countries. However, it is a relatively new field, especially in the Arab World. In the context of developing countries, the main underlying problem is for the poor to access and utilize financial services at a reasonable cost. (Malik \& Yadav, 2014; Kumar \& Mohanty, 2011; Gandhi, 2013; Demirguc-Kunt \& leora, wp.6088, 2012; World Bank, wp8314, 2013) measured and highlighted the financial inclusion indicators by countries, such as banking penetration, banking branches per individuals, ATMs per individual, and POS, while also comparing them to other countries in the region, on top of discussing the policies and procedures adopted from governmental institutions and other financial services providers. Demirguc-Kunt and leora (wp.6025, 2012), in their study, used interviews, phone calls, and cell phones to measure the financial inclusion indicator, in addition to utilizing the data available in the world bank index for 148 countries, such as banking penetration, insurance, saving, loans and mobile money. They confirmed that around $50 \%$ of adults in these countries do not have accounts in formal institutions while in the MENA region this figure is $75 \%$.

Clamara et al. (2014) analyzed the correlation between financial inclusion and the socioeconomic characteristics (individual characteristics) in Peru and its respective effect on financial inclusion adoption for individuals and enterprises. They determined that factors such as low income, women, low levels of education, and living in rural areas is increasing the financial exclusion.

Sarma (2008) developed a model to measure the financial inclusion level by countries, the study used three basic dimension (banking penetration, Availability of banking services, Usage), and the result from using this model depended on the data available. Sarma and Jesim (2011) used the index developed by Sarma (2008), and confirmed that the relationship between financial inclusion and the development to be strongly positively correlated, and also determined that the available infrastructure improves the levels of financial inclusion. Akhtar and Pearce (2010) discussed the microfinance industry in MENA and the relationship between microfinance; NGOs and financial inclusion also discussed the Regulatory Structures; infrastructure in MENA countries, in addition to addressing some approaches of financial inclusion and opportunities in MENA countries. The study also concluded that Arab countries suffers from high financial exclusion, but there are a several initiatives by central banks or formal institutions in enhancing the role of MFIs in achieving financial inclusion, such as Egypt, Yemen, Morocco, and Syria.

Pearce (2011) measured the financial inclusion in MENA and use them as indicators for other regions in the world. He also addressed the effect of the financial crisis on financial inclusion and highlighted Islamic microfinance opportunities. The study addresses the fact that there are five countries in the region possessing the strategies to achieve financial inclusion. Only $21.3 \%$ of adults have bank accounts, while the role of microcredit is still limited. Bruhn and love (2009) used the Azteca bank case to determine the impact of banking penetration policy to target low-income individuals on economic development. The bank has more than 800 branches in 2002 , and the study found that employment increased by $1.4 \%$, and the average income increased to around $7 \%$, while informal business owners increased by $7.6 \%$ as a result of these branches.

Aduda and Kalunda (2012) browsed the financial inclusion through literature, and they concluded that most of the global population is out of the reach of financial inclusion while also suffering from social exclusion. Furthermore, the study found that the achieving financial inclusion is important in the context of financial stability. The existence of a regulated market for security trading is one of the growth and economic development factors in the country for its contribution in attracting savings and investment returns, on top of providing liquidity and funding for companies. A lot of studies were done on the stock market and economic growth; Ben Naceur and Ghazouani (2006) used GMM estimates to determine whether or not there is a relationship between the banks and the stock market development and economic growth in MENA. The results from this study is unexpected, as it was determined that the relationship between banks and stock market development is unimportant, and it was concluded that the reason for this is a weak financial system and decline in the economic growth. Levine and Zervos (1998) determined that we could predicate economic growth on the development in banking sector and stock market. Also, Beck and Levine (2004), in their study, found that the development in the banking sector and stock market is strongly correlated with economic growth. 
This study will highlight financial inclusion in the context of Palestine. Also, the policies and procedures followed by government institutions such as the Palestine Monetary Authority (PMA) and Palestine Capital Market Authority (PCMA) will be viewed through which the financial service companies achieve and enhance financial inclusion as a path to growth, which will be done alongside the analysis of financial inclusion indicator of countries in the MENA region. Finally, the stock market was included as a strong factor to the main indicators (Access, usage, and quality) of economic growth.

\section{Methodology and Data}

The study is based on analyzing the financial banking and demographics data (secondary data) collected from different sources, on top of analyzing government policies and procedures to achieve financial inclusion. Financial inclusion indicators will be analyzed and discussed as well. The indicators will also be displayed in the charts and diagram to be compared to the indicators of other countries in the region.

The main data was collected from the Palestine Monetary Authority (PMA) annual reports, statistics and publications, Palestine Capital Market Authority (PCMA) annual reports and statistics, Palestinian Central Bureau of Statistics (PCBS) Publications and statistics, Association Banks in Palestine, World Bank-Global findex, World Bank researches, Consultative Group to Assist the Poor (CGAP), International Monetary Fund( IMF), Alliance for Financial Inclusion (AFI), Palestinian International Banking Conference brochure 1\&2, Palestine Exchange statistics (PEX), Central Bank of Jordan, and the Association of Banks in Jordan.

\section{Financial Inclusion-Definition, Policies, Status and Indicators Analyzing}

\subsection{Financial Inclusion Definition}

The definition of financial inclusion differs in researches and literature. Most researches include access to financial services and how to use it in the definition, alongside the impact of using financial services on economic development. The CGAP definition "Financial inclusion means that households and businesses have access and can effectively used appropriate financial services. Such services must be provided responsibly and sustainably, in a well regulated environment". Consultative Group to Assist the Poor website. The PMA defined financial inclusion as enhancing the access to the financial services for all groups in the society, with fair, transparent, and affordable costs (PMA website). (Aduda \& Kalunda, 2012) defined financial inclusion as benefiting from financial services at an affordable cost in a suitable place, time, and form, without discriminating against members of the society.

G20 determined the three main indicators for financial inclusion for measurement across nations. Each main indicator contains several criteria for individuals and firms i.e. (Access to financial services, usage of services, the quality of the products and the service delivery). This paper will address the financial inclusion indicators in Palestine, which can be analyzed through the data collected from different sources, in addition to include a new factor, which is the stock market, "as it importance in economic development".

\subsection{The Government Policies and Procedures to Achieve Financial Inclusion in Palestine}

The Palestinian government is interested in achieving and enhancing financial inclusion through laws and policies issued by the PMA and PMCA. These authorities aim to achieve financial and monetary sustainability and enhance the economic growth through the supervision and control procedures that regulate financial institutions activities, as financial inclusion is one of the factors that help achieve economic growth and stimulation. Governmental institutions seek to include the society into the financial system in order to benefit from services and products needed in their daily life. Since the PMA has joined to the AFI, it has been working towards adopting several policies aimed at achieving financial inclusion in Palestine by:

1) The PMA is the supervisory authority of banks, specialized lending institutions, and money exchangers, while the PCMA is the supervisory authority of non-banking financial institutions, insurance companies, mortgage, and leasing. The stock market and financial intermediation signed a memorandum of understanding in 2013 to implement the national strategy for financial inclusion in Palestine to unify and coordinate efforts and not waste resources through standardized work in promoting financial inclusion.

2) SMEs contribute about 55\% of the GDP, as well as representing $91 \%$ of the total existing firms in Palestine (PMA, annual report, 2013). With the aim of strengthening the role of these enterprises in the process of economic growth and to highlight the financial needs and ways for providing these financial needs, the PMA hosted an international banking conference entitled "Empowering Small and Medium Enterprises in Palestine through Enhancing Access to Finance". The objective of this conference was to increase interest in these enterprises and to overcome obstacles in order to obtain the appropriate sources of funding. Lower borrowing conditions and the reduction of the terms of the restructuring of the debt owed in terms of 
reducing the payment of non-performing loans ratio are generally preferred. In contrast, the PMA proceeded to exempt banks from risk reserve requirement at a $2 \%$ ratio for credit facilities granted to these enterprises. Also, a database was created especially for SMEs in order to provide all financial data and help banks direct the products and services needed by this sector. Furthermore, the conference of "financial inclusion: path of growth", which was held at the end of 2014, addressed the future prospects of financial inclusion and promote financial inclusion through innovative products and services that meet the needs of the community and offer tools and methods to strengthen it.

3) The PMA launched the annual banking week for children and youths in collaboration with the Ministry of Education and Higher Education, the Association of Palestinian banks, and the Directorate of the UNRWA schools. The banks educated, during the events in 2013, thousands of students by visiting 232 branches. In addition, they met 87,000 students through visits held in the West Bank and Gaza Strip schools through 1,600 schools, and managed to distribute of 170,000 brochures (PMA, annual report, 2013). PCMA continued the financial awareness campaign to achieve financial inclusion. The campaign aimed to raise the awareness of small shareholders on subjects such as their rights, voting mechanisms, and the ordinary and extraordinary meetings of the General Authority. The insurance day programs were held in universities, where a delegation from the PCMA and insurance companies visited the campus. A program was instituted in local universities on financial education, which incorporated expert participation from the PMCA. Further participation will also involve training selected employees via e-awareness and educational newsletters.

4) The PMA has worked on restructuring the banking system to enhance its ability to provide innovative banking products and services, on top of the competition and branching, through liquidating weak banks either by choice or making it compulsory (The Principal Bank for Development and Agricultural Credit in 2009, Al-Aqsa Islamic Bank, in 2010, Palestine international Bank in 2010). Covering multiple geographical areas, with priority in rural regions, strengthens the branches of the banks, which will also aid in increasing the banks' ability to face the expected risks and increase their competitiveness. Banks are also encouraged to open new branches abroad and improve the quality of services provided to the public. The expansion of electronic services cost USD 100 million, with the PMA working towards that goal.

The banks are prompted to diversify their services and the addition of modern electronic services. Such developments include online payments and transfers, which invariably improves the use of banking services and reduce costs (PMA, WP/12/01, 2011)

5) To enable the population to obtain banking products and services at an acceptable and affordable cost, the PMA issued instructions on the fees and commissions. The PMA stipulates that the banks announce these fees and commissions through websites and on billboards in all branches and offices, and also when providing the service to the customer. In addition, there is an upper limit of the funds the banks are allowed to receive or handle. The banks are urged to motivate customers to use credit cards instead of money. It also gave the bank the right to exempt customers from commissions in order to attract them.

6) The PMA launched a campaign entitled "Primary Bank Account for Each Citizen" (PMA, annual report, 2012), so that all citizens can get basic banking services at no cost or minimum balance, which suits their respective financial needs. The campaign targeted the poor/low-income and middle-class people, most of which lack a bank account. Banks are also directed to offer services to meet the objective of the campaign, such as (direct cash, deposit and withdrawals from the counter or through ATM, banking services via the Internet, pay bills automatically, money transfer, and providing an ATM card).

7) PMA \& PCMA have regulated many workshops, seminars, and education lectures for university students and associations. Also, they receive students in their headquarters and regulate visiting programs that espouse financial awareness in order to achieve financial inclusion.

8) The PMA launched instruction on ATM service in order to ensure the safety of the procedures in electronic dealings. Furthermore, they encourage citizens to benefit from ATM services and any related e-services by making these services easy and always available (PMA, annual report, 2012).

9) Increase public confidence in the Palestinian banking system. Depositors are protected, financial stability maintained, and economic growth promoted via the establishment of the Palestinian Deposit Insurance Corporation (PDIC) by the government on $29^{\text {th }}$ May 2013, which became operational on $26^{\text {th }}$ Sep 2013 , covering $93 \%$ of the depositors in the banking system.

10) The PCMA issued a leasing law, many of the standards and performance measurement cards, which 
evaluate Palestinian companies and its respective governance, and the issuance of "Palestinian securities sector rules and regulations". This also involves the development of regulatory laws on the securities industry, insurance, and project development programs specializing in securities and investment professional certification. Several instructions, such as margin financing, administration, and auditing instructions in securities companies, instructions on granting leave for the banking insurance, modifying financial mortgage actively, increase the margin of fluctuation of stock prices, and the extension of the continuous trading period in Palestine Exchange was incorporated as well (PCMA, annual report, 2013).

\subsection{Status and Analyzing the Financial Inclusion Indicators in Palestine}

This section includes the analysis and the discussion of the financial inclusion indicators in Palestine and its comparison to other indicators in certain countries in the region. On top of these indicators measured in the literature, this study will discuss and analyze some figures about stock and bond market on the Palestine stock exchange (PEX). The indicators that were analyzed are:

1) The number of banks reached 17 (7 local banks, including two Islamic banks, and 10 foreign banks), and the total number of their branches and offices is 255 branches and offices as of 2014 (PMA, annual report, 2013). The total number of banks in Lebanon was 73, while in Jordan; there were 26 banks as of 2013.

2) The bank branches distribution between large cities and rural areas is $55 \%$ and $45 \%$, respectively, as of 2013, shown in Figure (1).

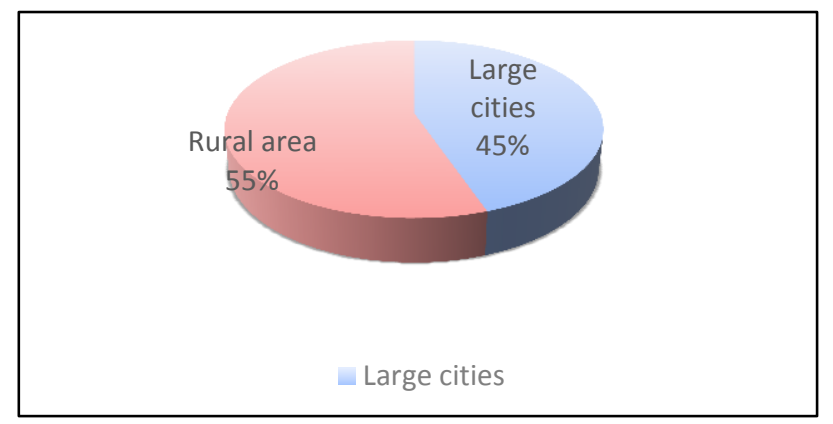

Figure 1. The branches distribution between large cities and rural area

3) The individuals per branch, which is 17,844 individuals as of 9/2014, are shown in Figure number (2). Thereby, it exceeded the accepted rate in the world, which is 10,000 individuals per branch (The number of bank branches per 100,000 adults that are more than 15 years old is 8.8 branches, and the area per Km 2 branch $25.4 \mathrm{Km} 2$ as of 2013). The average number of individuals per branch as of 2014 in the West Bank is 13,415 individuals while it is 37,448 in the Gaza Strip. The number of bank branches and offices in the West Bank is 208, which is 82\%, while in the Gaza Strip, it is 47, equaling 18\% (PMA annual report, 2013). In Lebanon, it is 5, 000, while in Jordan, it is 7,957 individuals per branch as of 2013.

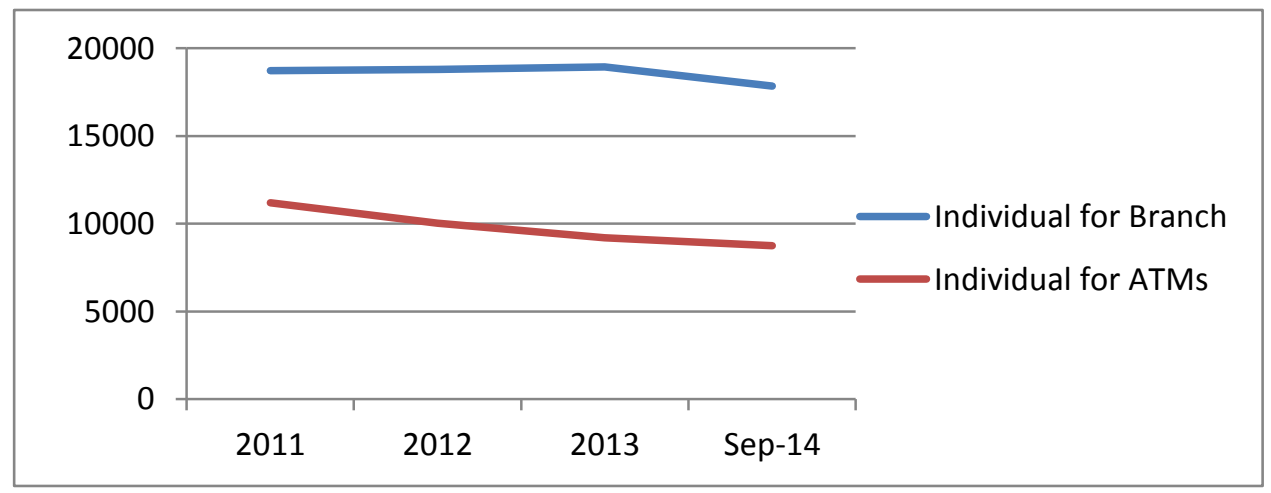

Figure 2. Individual per banking branches \& ATMs 
4) The Automatic teller machines (ATMs) increased from 305 ATMs in 2009 to 521 ATMs as of 30th September 2014. Also, the number of ATMs in accordance with Palestine's total area (the West Bank measures $5655 \mathrm{~km} 2$, while the Gaza strip measures $365 \mathrm{~km} 2$ ), there is one ATM per $11 \mathrm{~km} 2$ as of 30th September 2014. Every ATM covered 8,733 individuals as of 30th September 2014.

The number of ATMs per 100,000 adults that are above 15 years of age is 18.1 as of 2013, distributed in the West Bank a total of 454 ATMs (87\%), while in the Gaza Strip, it is 67 ATMs as of 30th September 2014 (PMA, Reports, 2014), whereas in Lebanon, it is 2,947, and in Jordan, it is 4851 individuals per ATMs as of 2013.

5) The number of point of sales (POSs) increased from 1,745 in 2009 to 5,280 until $30^{\text {th }}$ September 2014. (Number of POSs per 100,000 adults above 15 years old is 172.3 as of 2013; West Bank "79\%", and Gaza Strip "21\%"). Also, the issuance of Credit Cards increased from 29,082 as of 2009, to 68,076 cards as of $30^{\text {th }}$ September 2014. In addition to the increase in the number of debit cards from 285,228 as of 2009 , to 439,075 cards as of $30^{\text {th }}$ September 2014 (PMA reports, 2014).

The ATM withdrawal cards increased from 68,185 as of 2009 to 155,798 as of $30^{\text {th }}$ September 2014. Figure number (3) shows the increase in the use of electronic payment by customers from 2009 until September 2014. The POS in Lebanon is made up of 30,517 POS (manual machine, electronic machine) as of September 2014, while in Jordan; it was 28, 200 as of 2013.

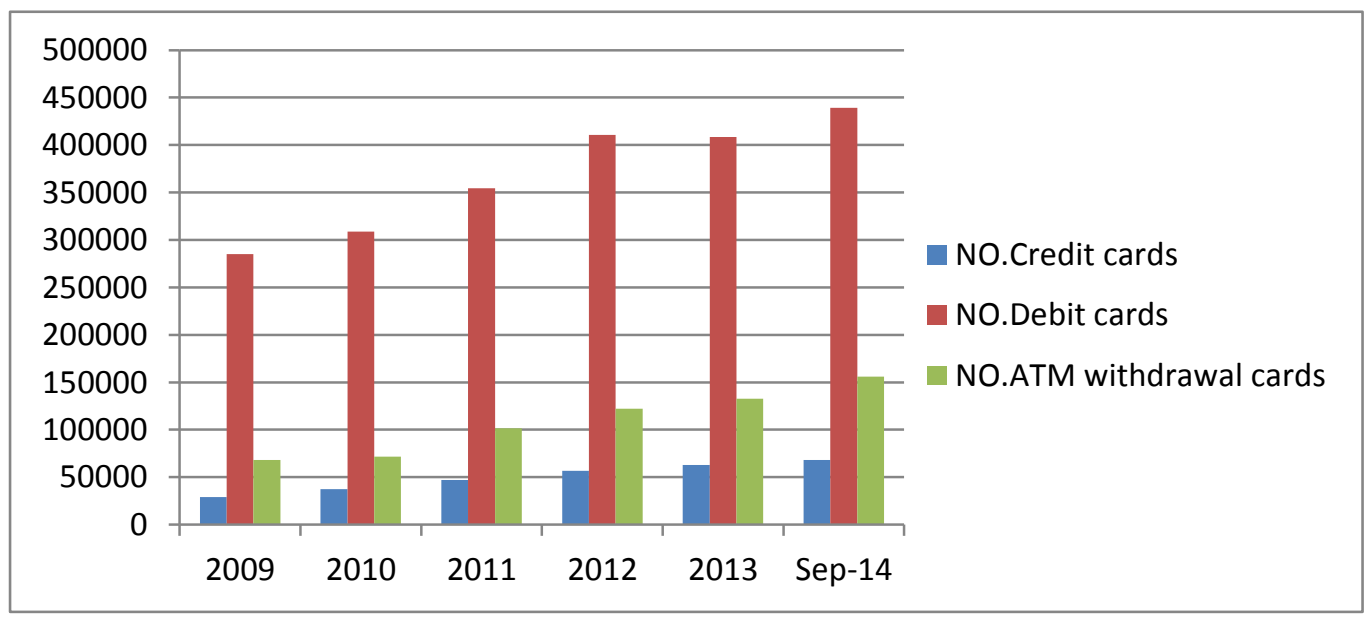

Figure 3. Growth of number credit and withdrawal cards

6) The banking accounts, as a result of the penetration policy, issued instructions regarding the opening of an account for each citizen/Basic account, and ATM services have contributed in improving the financial inclusion indicators in Palestine. The percentage of adults who have current accounts and deposits with the banking system were about 59\% of the total number of adults as of 201312 (in the MENA region, $18 \%$ of adults have an account in the banking system).

The numbers of customers benefiting from the campaign account for each citizen were almost 60,000 in 2012 and 84,000 accounts in 2013 (PMA, annual report, 2013). There was an increase in the number of depositors' accounts with the banking system, from 2,011,242 as of 2009, to 2,913,502 accounts as of 30th September 2014 (as a percentage from the total population is 62\% as of 2013, and the number of Deposit Accounts per 1,000 adults who are above 15 years of age is 1019).

7) The Palestinian economy suffer from chronic shortage of facilities and credit despite the abundance of deposits, which increased from 6296.8 million US\$ as of 2009 , to 8883.9 million US\$ as of $30^{\text {th }}$ September 2014, but the development of the total grants increased from 2234.2 million US\$ as of 2009 to 4843.4 million US\$ as of $30^{\text {th }}$ September 2014 (as a percentage of GDP in the current price, the deposit was $61.13 \%$, while the credits was $24.9 \%$ as of 2013). furthermore, the adult beneficiaries of the lending sources are only $10 \%$. Also the $32.7 \%$ of the total private sector facilities in 2013 went to funding consumables and automobiles, followed by real estate, construction, and land at $22.8 \%$, while agriculture and livestock represents $1.2 \%$ of the facilities (PMA, annual report, 2013). 
Private deposits in Lebanon totaled 107.7 billion US\$, while private credit totaled 47.4 billion US\$, while in Jordan, private deposits totaled 35.727 billion US\$, while private credits totaled 17.3871 billion US\$ as of 2013 .

These increasing development in deposits and credits in Palestine are shown in Figure 4, while Figure 5 show the comparative Private Sector Deposits as \% of GDP in Lebanon, Jordan, and Palestine as of 2013.

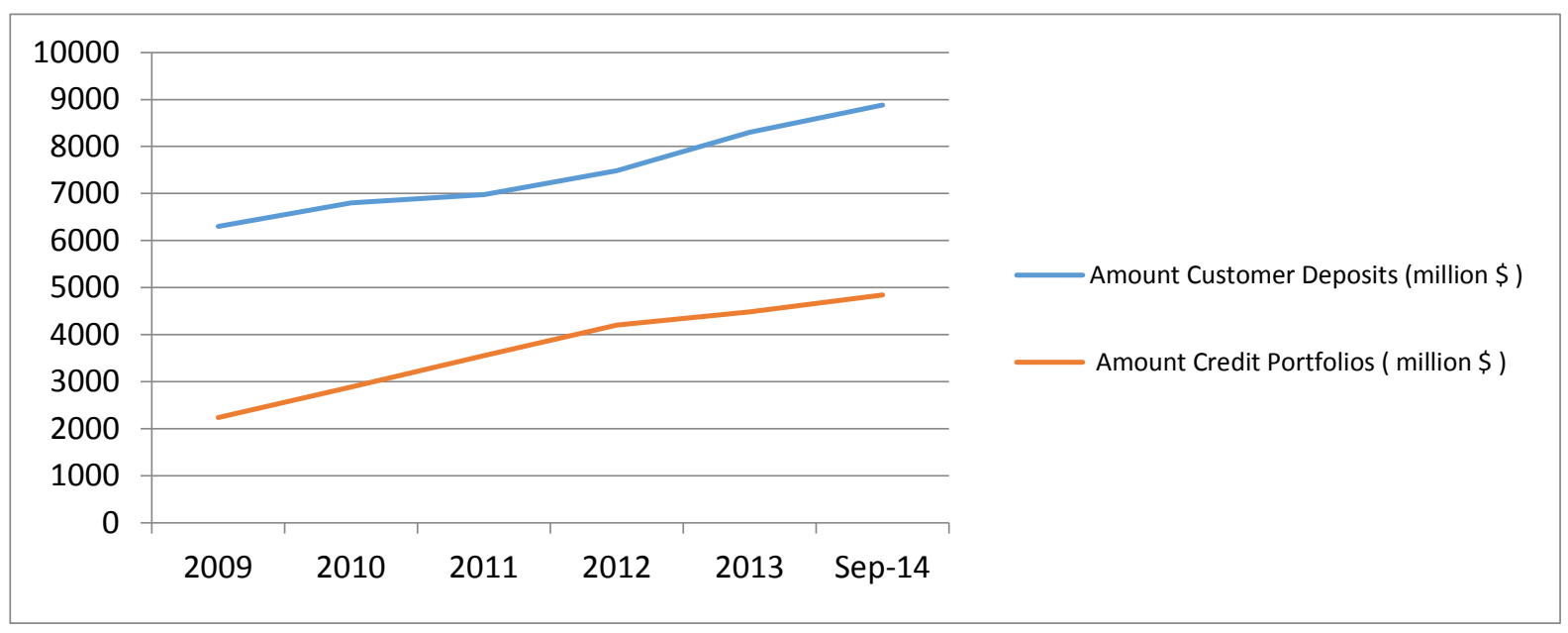

Figure 4. The increasing in customers' deposits and credits

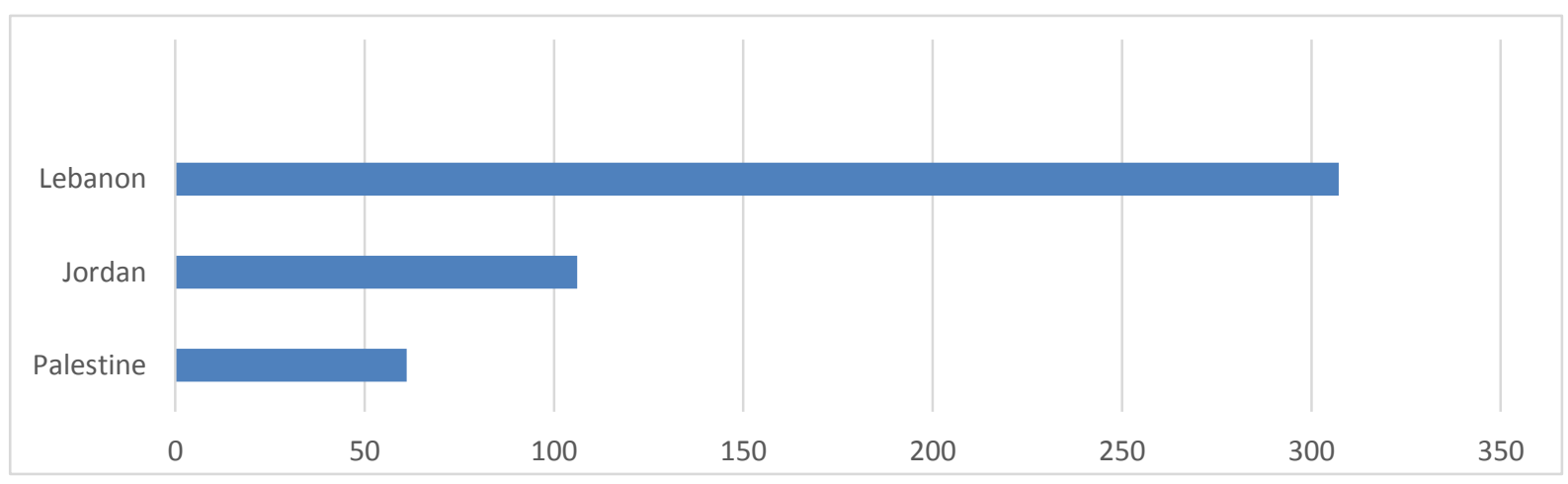

Figure 5. Comparative private sector deposits as \% of GDP in current price as in 2013

8) The number of money exchangers increased throughout the last six years, peaking at 291 money exchangers as of 2014. Correspondingly, it is 232 in the West Bank and 38 in the Gaza Strip. The number of exchangers operating as a company is 184 , while 86 were individual firms as of 2013. Jordan has 142 with 237 branches, while Lebanon has 384 as of 2013.

9) There are six lending institutions that were approved for initial licenses to conduct its work in Palestine (The total number of operating institutions and programs in the field of specialized lending in Palestine 13 institutions and programs are operating through 72 branches). Furthermore, the number of loans granted by 6 institutions licensed by the PMA is 39,898 loans as of 2013. From a total amount of 85.4 million US\$ with more than 54,000 borrowers, half of them are females. Also, the total loans of the small lending institutions portfolio was 84.2 million US\$ in 2012, and 85.4 million US\$ as of 2013 , while the microfinance institutions in Lebanon has 6 institutions, while Jordan has 3 as of 2013.

10) The insurance sector has achieved a growth rate of $10 \%$ in 2013, on top of a remarkable growth of $68 \%$ since 2008 to 2013, and an increased insurance portfolio of 94,310,529 US\$ in 2008 to $158,707,973$ US $\$$ in 2013. The number of insurance companies reaching Palestine is 10 companies, with a total of 114 branches and 225 insurance agents, in addition to the 1,075 employees in insurance companies' branches as of 2013. There are 59 insurance company in Lebanon and 59 in Jordan as of 2013. 
11) The value added 2 in the financial intermediaries institutions 3 was 353.9 million US\$ (305.7 million US\$ in banks and financial institutions, 38.4 million US\$ in insurance companies, and 9.8 million US\$ in money exchangers) as of 2013. The achieved production 4(output) financial intermediaries' institutions in 2013 were 470.6 million US\$ (banks and financial institutions production reached 379.7 million US\$, insurance companies 67.6 million US\$, and currency exchange firms 13.4 million US\$). However, the contribution of financial and insurance activity in the GDP decreased from $3.7 \%$ in 2012 and fell to $2.8 \%$ in 2013.

Furthermore, the increase in the GDP of Palestine from 5724.5 million US\$ in 2010 to 7286.9 million US\$, as expected in 2014. However, the economic growth rates declined, where the growth rate in 2011, 2012, 2013, and 2014 were $12.2 \%, 5.9 \%, 2.1 \%,-2.5 \%$, respectively. The economic growth in Jordan was $3 \%$ and Lebanon was $1.5 \%$ as of 2013 .

12) The direct impact for branching appears in increased hiring of employees in the banking sector, the employees as of 2010 were 4687, reaching 5379 as of 2013(PMA, annual report, 2013). The employees in the Jordanian banking sector are 18423, while the Lebanese banks employ 23136 as of 2013 (Association of Banks in Jordan, Association of Banks in Lebanon, 2013).

13) Stock Market as a Financial Inclusion Factor: As shown in the literature with the notable exception of Ben Naceur and Ghazouani (2006), there is a strong correlation between stock market development and economic growth internationally. To make this relationship more efficient in Palestine and enhance the economic growth, government policies through PCMA and Palestine stock Exchange (PEX) included individuals and firms to invest in the stock and bonds market. Those investments benefit individuals by attracting deposits and savings to realize revenues and maximize their wealth, while also protecting their capitals. Furthermore, these policies benefit larger firms, however, they also encourage smaller firms to enter the market and obtain financing, which will improve their chances of obtaining credits from banks and lending institutions that will contribute to excellent economic growth in Palestine. In order to utilize these targets as a path to financial inclusion and growth, the stock and bonds market will be made strong factor for financial inclusion.

The trading in Palestine Exchange (PEX)-representing the stocks and bonds market in Palestine-began on $18^{\text {th }}$ February 1997, where the listed companies in the market were a total of 49 companies in 2014, on top of one company that listed its bonds on the stock exchange and 8 brokerage companies.

The statistics showed good growth in key indicators of PEX in 2013 compared with 2012, where the Al-Quads index rose to $13.37 \%$ and the trade value rose by $24.62 \%$. Furthermore, the market value increased by $28.76 \%$, the total exchange volume by $37.79 \%$, and the number of transactions by $7.2 \%$.

The number of securities owned by Palestinian investors is one billion (63.65\%), valued at 1.83 billion US\$, which is $26.6 \%$ of the private sector's deposit as of 2014 (foreign investment of 1.35 billion US\$). The total number of Palestinian investors is 70,454 (95\%). Also, the gross value of securities is 3.2 billion US\$, with more than 1.63 billion securities and 73,959 investors. The gross value of securities, as a percentage from the GDP, is $44 \%$ as of 2014.

The PEX contribution in financial and investment awareness is significant via the issuance of the capital market magazine in a periodical manner, holding seminars for students and visiting academics, and hosting students and universities. The PEX received in 2014 was about 1,500 students from schools and universities. Additionally, a conference specializing in developments in terms of investment in securities and attracting investors to invest in PEX is held annually. The implementation of simulation of the stock exchange competition at Palestinian universities was done since 2009 with the aim of educating and training students on the mechanics of investing in the stock market, thereby encouraging them to save money and invest in financial assets. In 2014, about 240 university students participated in the competition. Seminars were also held for local and foreign investors to encourage them to invest in PEX and seize promising investment opportunities in the Palestinian market. Table 1 show the comparative in financial inclusion indicators between Palestine, Jordan and Lebanon. 
Table 1. Comparative in financial inclusion indicators between Palestine, Jordan and Lebanon

\begin{tabular}{cccc}
\hline Indicators & Palestine & Jordan & Lebanon \\
& $9 / 2014$ & 2013 & 2013 \\
\hline No. Banks & 17 & 26 & 73 \\
Individuals per Branch & 17,844 & 7,957 & 5,000 \\
Individuals per ATM & 8,733 & 4,851 & 2,947 \\
No. POS & 5,280 & 28,200 & 30,517 \\
\% population has account in formal financial institution & $62 \%$ & $25.47 \% *$ & $37.02 \% *$ \\
Deposits/GDP*** & $61.13 \% * *$ & $106 \%$ & $307.25 \%$ \\
Credits/GDP & $24 \% * *$ & $51.6 \%$ & $242 \%$ \\
No. Money Exchanger, Insurance Co., MIFs & 314 & 170 & 449 \\
No. Bank's Employees & 5,379 & 18,423 & 23,136 \\
Stock Market Capitalization as \% of GDP** & $25.65 \%$ & $76.36 \%$ & $25.45 \%$ \\
\hline
\end{tabular}

Sources: central banks and association banks in Palestine, Jordan, Lebanon. *: 2011, **: 2013, *** GDP in current price.

\section{Challenges}

The main obstacle in Palestine is the lack of political and economic stability, leading to the reluctance of individuals and institutions to borrow or utilize funding sources. Thus, individuals opt for government jobs instead of setting up their own business. We see that the contribution of some productive activities in the GDP declined in 2014 for items such as agriculture (7\%) and construction (10\%). Furthermore, the irregular public sector salaries led to irregular loan premiums granted by financial institutions. Individuals will also consume their savings dedicated for investments in firms.

The financial leasing and mortgage sector contribution in the financial inclusion is still poor. Up till this research, there are no special laws to regulate the mortgage finance sector; instead, it was replaced by a set of instructions that is intended to assist the development of the sector. These sectors are made up of fewer companies due to the lack of law guaranteeing protection. There is only one company that works in the mortgage business via a subsidiary.

Furthermore, the lack of an integrated geographic correlation in the Palestinian territories weakens the process of achieving financial inclusion and hampering the stability of economic growth rates.

\section{Conclusion and Recommendations}

The analysis and discussion shows the reality and the infrastructure of financial inclusion in Palestine. The current situation of financial services being provided reduces unemployment and increases growth.

\subsection{Conclusion}

The improvement in the infrastructure of financial services encourages individuals and small firms to take advantage of the financial services. This improvement include a number of branches and banking offices, ATMs, credit and debit cards, POSs, the amount of deposits and facilities, opened accounts, money exchangers, MFIs loans, branches and offices of insurance companies, employees in financial institutions, investors and value of securities in the stock market and bonds. The development of the laws, regulations, and instructions issued by the regulatory financial institutions (PMA, PCMA) help improve individuals' access to institutions and the financial system. These improvements alleviate the inaccessibility of the poor and improve their standards of living.

The tools and methods in financial education include financial institutions such as educational pamphlets, seminars and workshops, training courses, participating in the training of students and the hosting of financial institutions, visiting universities and schools, and educational competitions, and subsequent employment for university students. This is indicative of the fact that the infrastructure involving financial inclusions is very well developed.

Despite this marked improvement, the adult beneficiaries of the lending sources are only $10 \%$. This represents a negative indicator on the utilization of funding sources. Analysis also showed that the facilities for productivity sector was declined in 2013 such as; agriculture and livestock which represents $1.2 \%$ of the total facilities. This is rather indicative of the decline in productivity and economic growth.

The Gaza Strip suffers from poor infrastructure for financial inclusion and lower indicators (number of branches, ATMs, POSs, credit, deposits), despite the high population density in small areas, due to the high levels of 
poverty and unemployment, as opposed to the West Bank. The weakness in the financial inclusion indicators in Gaza Strip is due to it being constantly besieged and the threat of war, leading to stagnation of banking developments. These aforementioned conditions led to increasing unemployment and decreasing economic growth.

It was also determined that the financial inclusion indicators in Jordan and Lebanon are superior to Palestine as a result of political and economic stability. Examples of these indicators are branches number, ATMs, POS, credits and deposits, and individuals' per branch and ATMs.

This improvement in the financial inclusion indicators is the result of restructured and integrated effort by governmental institutions such as PMA, PCMA, in addition to the financial services institutions. The impact of this effort in the economic growth as the final target is still minor and inadequate without political and economic stability to develop Palestine.

\subsection{Recommendations}

In order to remove the obstacles of achievement the financial inclusion, government institutions should continue with their program of financial awareness, due to its significant impact on the promotion of financial inclusion. Furthermore, the prices of Internet access via mobiles should be reduced, and financial apps should be licensed and encouraged in order to encourage consumers to utilize electronic methods. This will prove to be a catalyst that will encourage financial lending institutions and banks to provide banking facilities at favorable terms for small businesses. This also involves promoting Islamic finance, development, and marketing of new financial products and effective services to ensure their perpetual use.

Finally, individuals should conduct a field survey to determine the factors impeding access to the financial system.

\section{References}

Akhtar, S., \& Pearce, D. (2010). Microfinance in the Arab World: The challenge of financial inclusion.

Beck, T., \& Levine, R. (2004). Stock markets, banks, and growth: Panel evidence. Journal of Banking \& Finance, 28(3), 423-442. http://dx.doi.org/10.1016/S0378-4266 (02)00408-9.

Camara, N., Peña, X., \& Tuesta, D. (2014). Factors that matter for financial inclusion: Evidence from Peru. Retrieved from https://www.bbvaresearch.com

Cull, R., Ehrbeck, T., \& Holle, N. (2014). Financial inclusion and development: Recent impact evidence. CGAP.

Demirgüç-Kunt, A., \& Klapper, L. F. (2012). Financial inclusion in Africa: An Overview. Policy research working paper 6088. World Bank.

Demirgüç-Kunt, A., \& Klapper, L. F. (2012). Measuring Financial Inclusion: The Global Findex database. Policy research working paper 6025, World Bank.

Enisan, A. A., \& Olufisayo, A. O. (2009). Stock market development and economic growth: Evidence from seven sub-Sahara African countries. Journal of Economics and Business, 61(2), 162-171. http://dx.doi.org/10.1016/j.jeconbus.2008.05.001

Gandhi, M. M. (2013). Financial inclusion: Indian initiatives in the global perspective. IOSR Journal of Economic and Finance (IOSR-JEF), 2(2), 27-40.

Kamath, V. (2010). Finding usage in access to banking and scope for microfinance in Gulbarga District, Karnataka: A study of Financial Inclusion on Below Poverty Line Families (Unpublished $\mathrm{PhD}$ dissertation). Padmashree Dr. D.Y. Patil University, Mumbai, India. Retrieved from http://dypatil.in/index.asp

Kapoor, A. (2014). Financial inclusion and the future of the Indian economy. Futures, 56, 35-42. http://dx.doi.org/10.1016/j.futures.2013.10.007

Kumar, B., \& Mohanty, B. (2011). Financial Inclusion and Inclusive Develoment in SAARC Countries with Special Reference to India. Vilakshan: The XIMB Journal of Management, 8(2).

Lederle, N. (2009). Exploring the impacts of improved financial inclusion on the lives of disadvantaged people (Doctoral dissertation, Heriot-Watt University).

Malik, R., \& Yadav, S. (2014). Financial inclusion in Indi: An appraisal. International Journal of Research (IJR), l(4), 593-602.

Naceur, S. B., \& Ghazouani, S. (2007). Stock markets, banks, and economic growth: Empirical evidence from the MENA region. Research in International Business and Finance, 21(2), 297-315. 
http://dx.doi.org/10.1016/j.ribaf.2006.05.002

Palestine Capital Market Authority. (2013). Annual Report 2013: 2014, Ramallah-Palestine. Retrieved from http://www.pcma.ps

Palestine Monetary Authority. (2011). Role of the Banking Sector in Developing the Palestinian Economy. Retrieved from http://www.pma.ps

Palestine Monetary Authority. (2012). Annual Report 2012. Ramallah-Palestine. Retrieved September, 2014 from http://www.pma.ps

Palestine Monetary Authority. (2013). Annual Report 2013. Ramallah-Palestine. Retrieved September, 2014 from http://www.pma.ps

Palestinian Central Bureau of Statistics. (2014a). National Accounts at Current and Constant Prices, 2013. Ramallah-Palestine. Retrieved from http://www.pcbs.gov.ps

Palestinian Central Bureau of Statistics. (2014b). Finance and Insurance Survey, 2013: Main Results. RamallahPalestine. Retrieved from http://www.pcbs.gov.ps

Pearce, D. (2011). Financial inclusion in the Middle East and North Africa: Analyses and roadmap recommendations. World Bank.

Petrous, J. (2012). The effect of the stock exchange on economic growth: A case of the Zimbabwe stock exchange. Research in Business and Economics Journal. University of Zimbabwe.

Sarma, M. (2008). Index of Financial Inclusion. Retrieved from http://icrier.org/publications/working-papers/

Sarma, M., \& Jesim, P. (2011). Financial inclusion and development. Journal of International Development, 23, 613-628. http://dx.doi.org/10.1002/jid.1698

Vittas, D. (1997). The Role of Non-Bank Financial Intermediaries in Egypt and other MENA countries. Development Research Group, World Bank.

World Bank. (2013). Financial Inclusion in Brazil: Building on Success 83140.

\section{Websites}

Alliance for Financial Inclusion website:http://www.afi-global.org

Association Banks in Palestine website: http://www.abp.ps

Association of Banks in Jordan website: http://www.abj.org.jo

Central Bank of Jordan website: http://www.cbj.gov.jo

Consultative Group to Assist the Poor website: http://www.cgap.org

International Monetary Fund website: http://www.imf.org

Palestine Monetary Authority website: http://www.pma.ps

Palestinian Central Bureau of Statistics website: http://www.pcbs.gov.ps

Palestine exchange statistics website: http://www.pex.ps

Palestine Capital Market Authority website: http://www.pcma.ps

\section{Notes}

Note 1. PMA, the conference of financial inclusion: path of growth, 2014.

Note 2. Value added is a central concept of production and refers to the generated value of any unit that carries out any productive activity. Gross value added is defined as the value of gross output less the value of intermediate consumption. The net value added is defined as the gross value less the value of fixed capital consumption. Finance and Insurance Survey Report; PCBS, 2013.

Note 3. Financial intermediation institutions are (PMA, commercial and Islamic banks, specialized lending institutions, Exchange, brokerage institutions, insurance companies, Money exchangers).

Note 4. Production (output) it is defined as the goods and services produced by an establishment, excluding the value of any goods and services used in an activity for which the establishment does not assume the risk of using the products in production, and excluding the value of goods and services consumed by the same establishment except for goods and services used for capital formation (fixed capital or changes in inventories) or own final 
consumption. Finance and Insurance Survey Report, PCBS, 2013palestine.

\section{Copyrights}

Copyright for this article is retained by the author(s), with first publication rights granted to the journal.

This is an open-access article distributed under the terms and conditions of the Creative Commons Attribution license (http://creativecommons.org/licenses/by/3.0/). 